\title{
GLOCHAMORE
}

\section{Global Change in Mountain Regions}

\section{$1^{\text {st }}$ Thematic Workshop "Global Environmental \& Social Monitoring"}

\author{
Vienna, Austria \\ $9-11$ May 2004
}

organized by

\author{
Institute of Ecology and Conservation Biology \\ University of Vienna, Austria \\ Laboratory of Paleobotany and Palynology \\ Faculty of Biology \\ Utrecht University, The Netherlands
}

Laboratoire de Glaciologie et Géophysique de l'Environnement

Centre National de la Recherche Scientifique, France

Soils and Biogeography, Glaciology and Geomorphodynamics

Geography Department

University of Zürich, Switzerland

Department of Botany

University of Basel, Switzerland 


\section{Background and Workshop Objectives}

Building on the results of the "kick-off" international workshop on "Global Change in Mountain Biosphere Reserves" held at the Entlebuch Biosphere Reserve (Switzerland) in November 2003, this first thematic workshop of GLOCHAMORE aims to develop an integrative working plan for environmental and social monitoring in mountain regions that will facilitate the implementation of global change research strategies in selected UNESCO MAB Biosphere Reserves. Sets of indicators should be defined to detect and analyse signals of changes in mountain regions and to study both direct cause-effect relationships in individual ecological systems as well as changes that derive from the complex interactions of different drivers of global change. Four parallel sessions covering different topics shall review latest developments in environmental and social monitoring strategies that are appropriate for mountain settings.

Working Groups:

- $\quad$ Cryospheric Indicators (Wilfried Haeberli, Jean-Pierre Dedieu)

- Terrestrial Ecosystems (Georg Grabherr, Michael Gottfried, Daniela Hohenwallner, Harald Pauli, Eva Spehn)

- Global Change Impacts on Mountain Waters - Past and Present (André Lotter, Roland Psenner)

- Social Monitoring (Martin Price)

The specific workshop objectives will be to identify concrete indicators that can be used to assess the impact of global change on mountain biosphere reserves, in particular with regard to the impact of global change on the biophysical environment and on the socio-economic condition of mountain people. Indicators will be defined at three different levels:

(a) basic level: indicators that can be monitored at relatively low cost with basic technological infrastructure, but which allow monitoring of global change in a comprehensive manner (all biosphere reserves should at least meet this level).

(b) intermediate level: indicators requiring more advanced technology or more financial means in general;

(c) advanced level: comprehensive array of indicators that can be applied by international networks focusing on climate change impacts and by comparable socio-economic monitoring programs.

For example the GLORIA network (Global Observation Research Initiative in Alpine Environments) focusing on monitoring the ecological impacts of climate change may be applied on a basic or intermediate level with GLORIA's Multi-Summit Approach or on the intermediate or advanced level with GLORIA's master site approach. Accordingly, in the area of socio-economic monitoring close collaboration is sought with programs such as BRIM.

\section{Workshop Product/Outcome}

(1) Concrete monitoring strategies for the selected Mountain Biosphere Reserves.

(2) Special issue in a peer reviewed journal / proceedings.

All participants are asked to provide a presentation on the relevant research activities for publication of the proceedings or peer-reviewed articles of Thematic Workshop 1 (TW1) in Vienna. In addition to power point presentations please provide a Word document (not exceeding 10 pages). 
Saturday, 8 May 2004

18:00 - 19:00 Arrival of participants and registration at the Institute of Ecology and

Conservation Biology for GLOCHAMORE First Thematic Workshop "Global Environmental \& Social Monitoring"

Evening free

Sunday, 9 May 2004

First Thematic Workshop “Global Environmental \& Social Monitoring”

Main objective: to develop an integrative working plan for environmental and social monitoring in high mountain regions

9:00 - 9:30 Welcoming address - Georg Grabherr

Opening remarks - Harald Bugmann

General Objectives - Thomas Schaaf

9:30 - 10:15 Presentation of Mountain Biosphere Reserves (Chairperson Georg Grabherr)

- Houria Khelifi (Algeria) Tassili N'Ajjer Biosphere Reserve

- Marco Cortes (Chile): Araucarias Biosphere Reserve

- Javier Sánchez Gutierrez (Spain): Sierra Nevada Biosphere Reserve

- Kallie Naude (South Africa): Kruger to Canyon Biosphere Reserve

10:15-10:45 Coffee Break

10:45 - 11:45 Overview on Working Groups

- $\quad$ Cryospheric Indicators (Wilfried Haeberli, Jean-Pierre Dedieu)

- Terrestrial Ecosystems (Georg Grabherr, Michael Gottfried, Daniela

Hohenwallner, Harald Pauli, Eva Spehn)

- $\quad$ Global Change Impacts on Mountain Waters - Past and Present (André Lotter, Roland Psenner)

- $\quad$ Social Monitoring (Martin Price)

11:45-12:30 Plenary discussion to identify/define the objectives and outcomes of the working groups (Chairperson Thomas Schaaf)

Logistics - Daniela Hohenwallner

12:30 - 14:00 Lunch (Reznicek)

14:00 - 18.00 Working Groups (parallel)

19:00

Welcome Dinner (Feuerwehr Wagner) 
9:00 - 10:10 Plenary session: presentation of preliminary results of Working Groups (5 min. presentation, 10 min. discussion for each WG) (Chairperson Georg Grabherr)

10:10 - 10:30 Aspects of Social Monitoring (Marina Fischer-Kowalski)

10:30-11:00 Coffee Break

11:00 - 12:30 Working Groups (parallel)

12:30 - 15:00 Lunch (working group chairpersons to combine results into one single report)

15:00 - 18:00 Presentation of the report at plenary (Chairperson Harald Bugmann)

Plenary discussion > synthesis, strategies

19:00

Farewell Dinner (Esterhazykeller)

Tuesday, May 112004

9:00 - 14:00 Excursion "Leopoldsberg" including lunch

Departure 


\title{
On the functions of social monitoring within BRIM
}

\author{
Marina Fischer-Kowalski
}

Institute for Social Ecology, Vienna

Faculty for Interdisciplinary Studies, Klagenfurt University 


\section{Outline}

- Status of the presentation: towards an Austrian MABresearch programme, with a special focus on BRIM

- using the MRI community for resonance and feedback

- point of departure: Rome Report 2001 on „Biosphere Reserve Integrated Monitoring“ (BRIM)

- Rome BRIM Report: a rich assembly of considerations, in particular on social monitoring. Next steps required: build on Rome report, narrowing down, becoming more specific and operational.

- State of the exercise: not answers, but good questions 


\section{The task of BRIM: sustainability monitoring}

“...Biosphere reserves are thus poised to take on an new role. Not only will they be a means for the people who live and work within and around them to attain a balanced relationship with the natural world; they will also contribute to the needs of society as a whole by showing the way to a more sustainable future. This is the heart of the vision for biosphere reserves in the 21 st century."

\section{Seville Strategy 1995}




\section{Tasks and functions of (social) monitoring}

- Description of States and Changes in Nature and Society and their interactions

- Early Warning: Timely diagnosis of potential damages, critical developments etc.

- Prospection of possible future developments

- Evaluation: Continuous control of targets, visions and management objectives

- Decision Support: Providing decision makers at different levels with relevant information

- Information and Communication

- Science: Providing data 
„From observation to monitoring“" (figure 1)

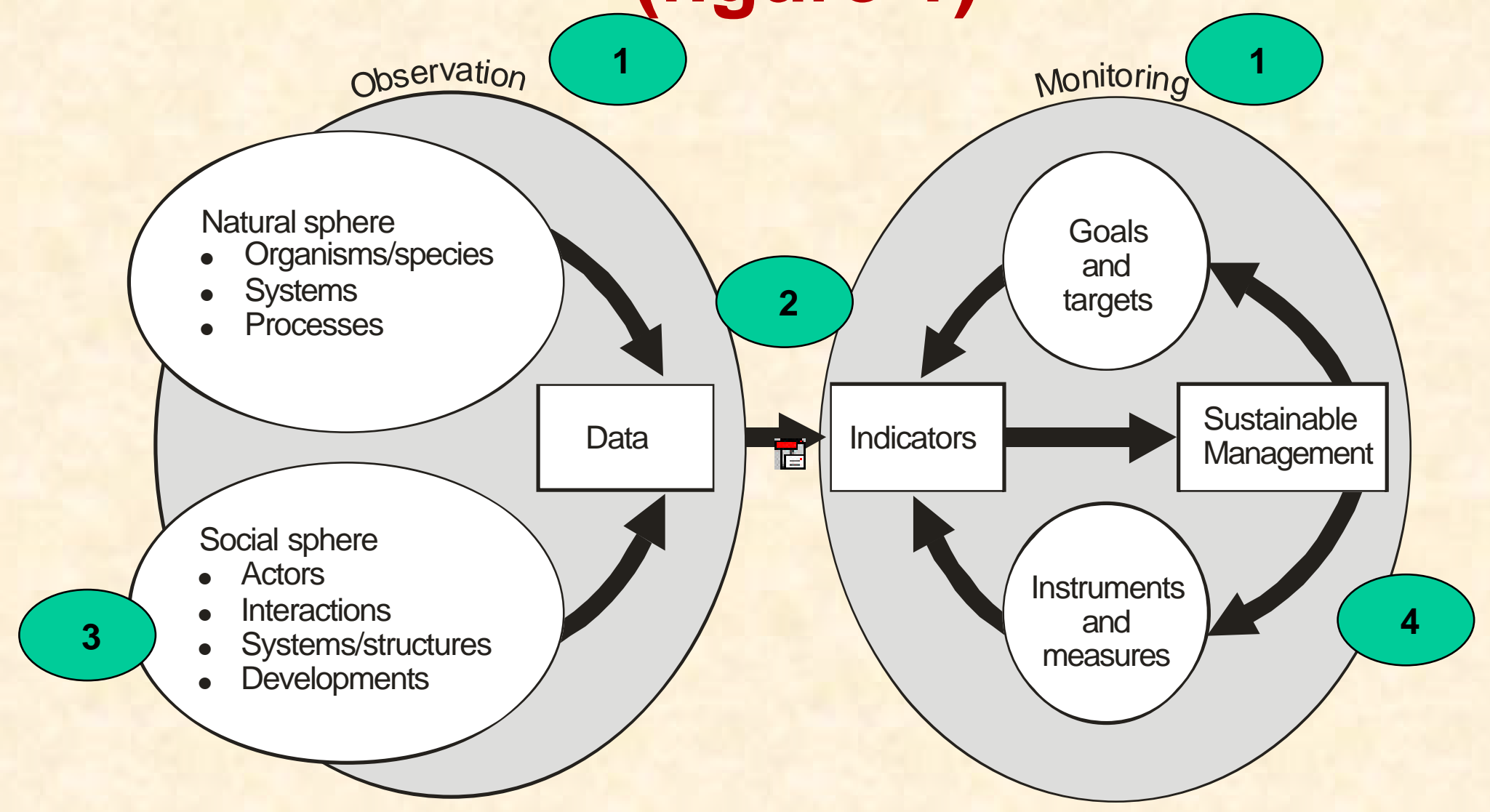

Source: Rome BRIM Report 


\section{Observation, monitoring and management interventions}

- „Monitoring“ in figure 1 (Rome report) extended very far into management activities and interventions: It contains goals and targets, and instruments, and management interventions.

- Oıır- -ation: separate „observation and monitoring“ $\mathrm{rd}$, „sustainability assessment and on the other.

- Lirı... . . vation and monitoring“ to „sustainability assessment and management" by analysis, nonroutine scientific efforts 


\section{Integrated monitoring - sustainability assessment \& management (fig $1^{\star}$ )}

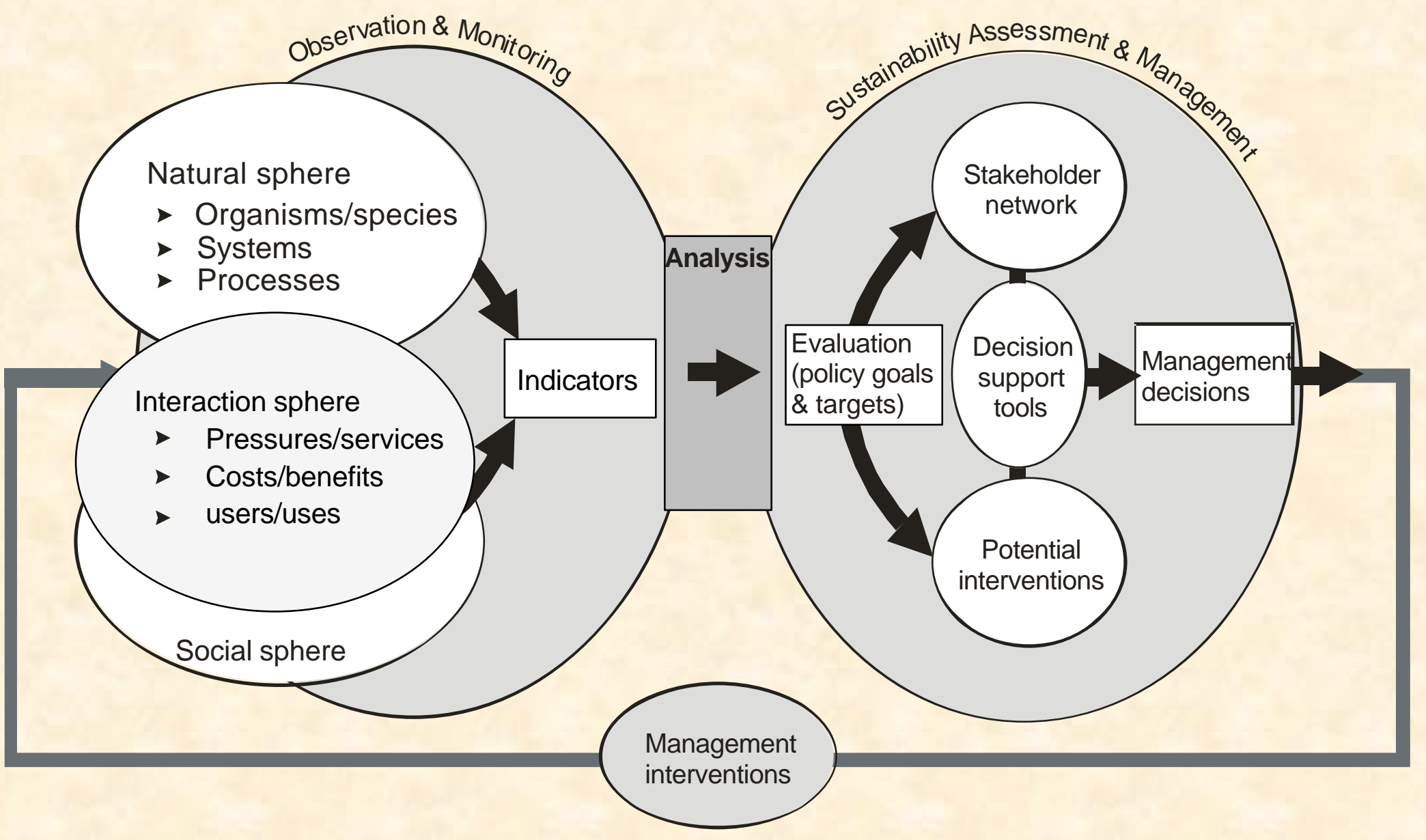




\section{„From observation to monitoring“}

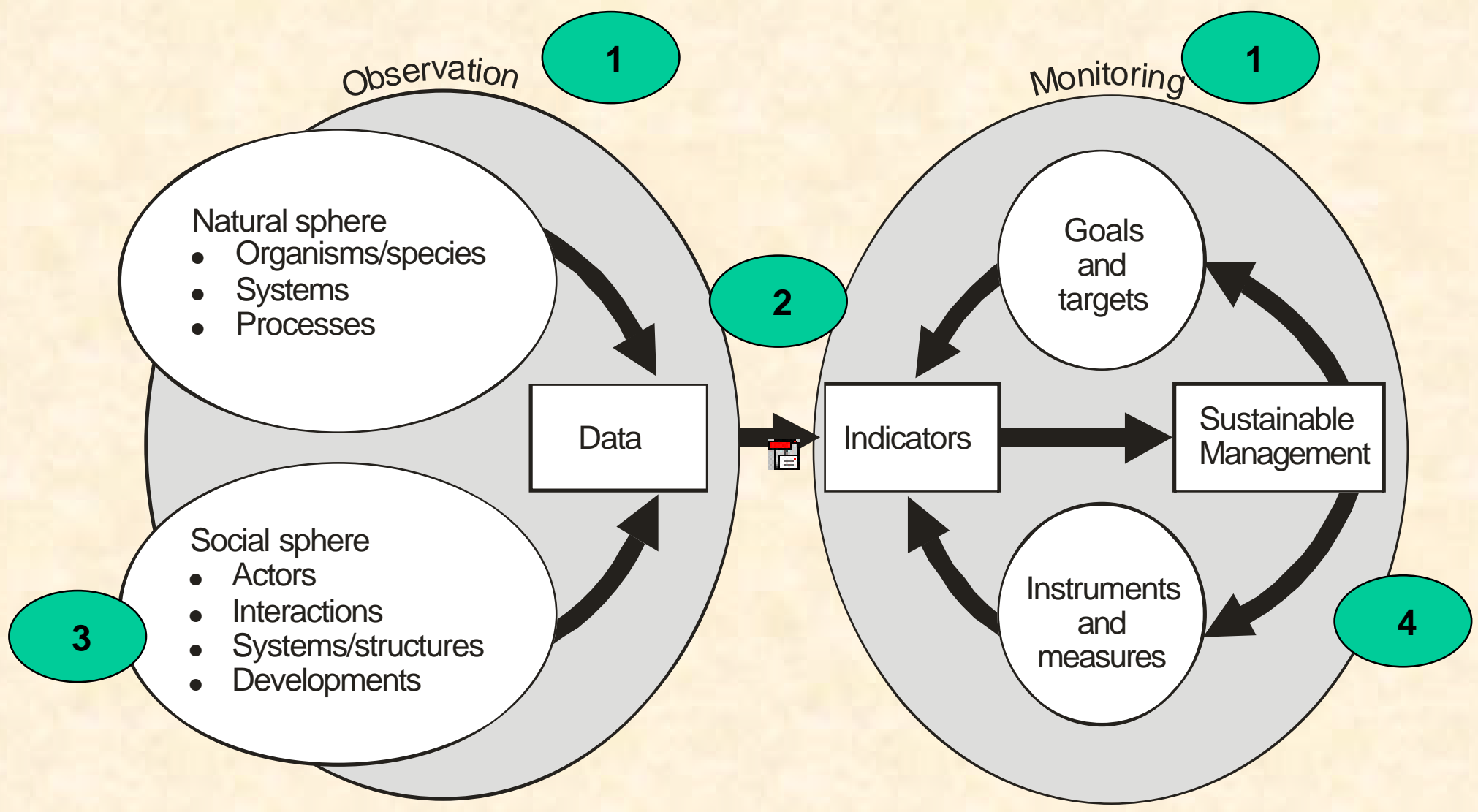

Source: Rome BRIM Report 


\section{Monitoring the "social sphere"}

- Focus on the key elements of the „social sphere“ relevant for sustainability:

- * users / uses

- * pressures / ecosystem services

- * costs / benefits.

- WHY? 


\section{Key to sustainability: interaction between social and natural system}

"It is necessary to establish a search process for an integrative framework for both natural and social monitoring that is open and flexible enough to adopt new theoretical and empirical evidence. Guiding principle should be the search for major human-nature interactions in biosphere reserves and the hypotheses that social and natural sciences have with regard to them." 
Outline of a simple conceptual model for the interaction social / natural systems

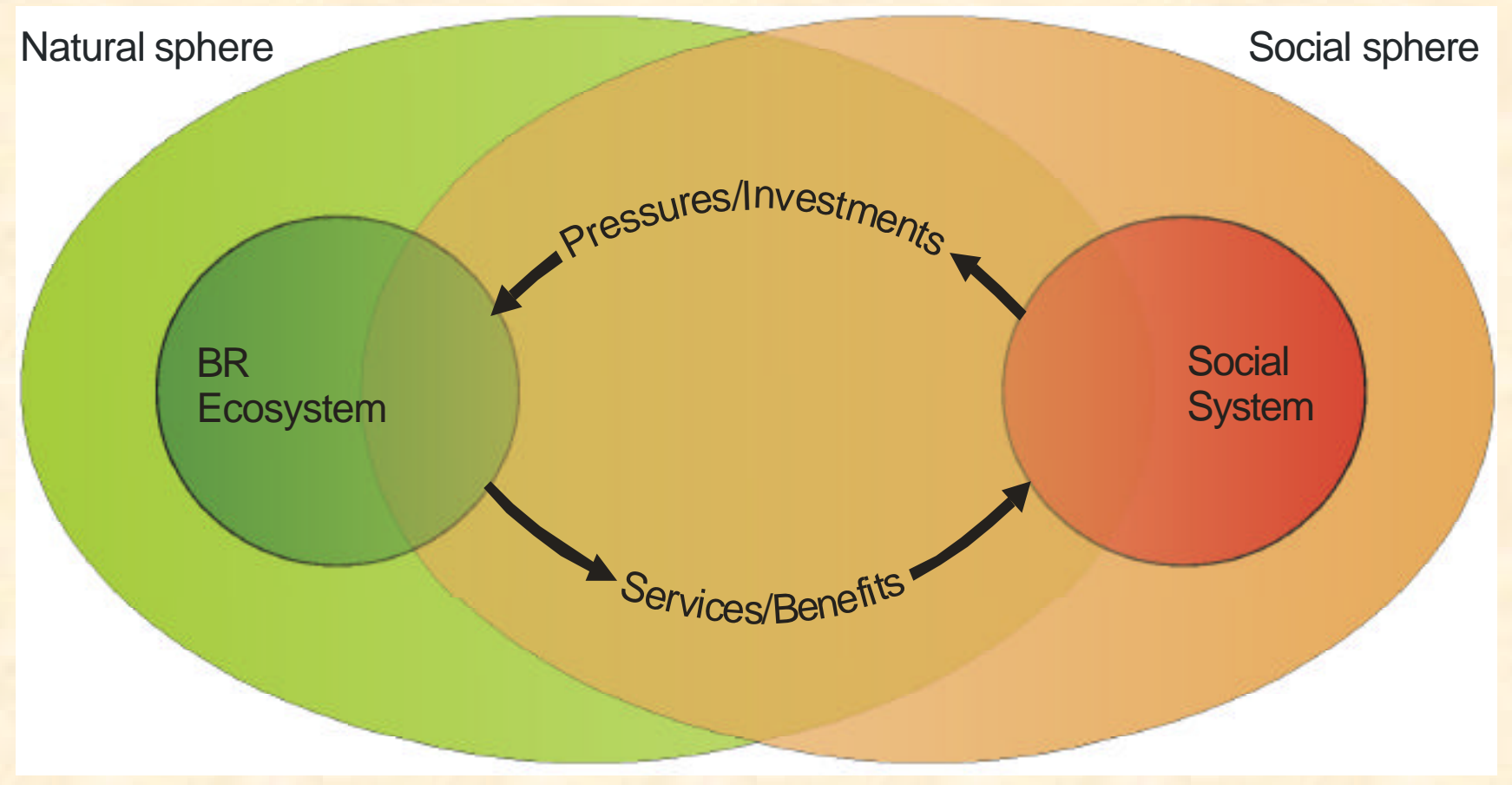




\section{Indicators for social monitoring}

- Basic demographics and well-being of people

- Ecosystem use

- Socio-economic dynamism

- Management, participation and governance

- Values and attitudes

- Information, education and research

- Future seen through the eyes of experts and inhabitants 


\section{stakeholders and users of BRs}

\begin{tabular}{c|l|l|l}
\hline \multicolumn{1}{|c|}{ scientists } & decision makers & \multicolumn{1}{c}{ users } \\
\hline $\begin{array}{c}\text { Interactions } \\
\text { with BR } \\
\text { ecosystem }\end{array}$ & $\begin{array}{l}\text { - measuring, monitoring, } \\
\text { assessments }\end{array}$ & $\begin{array}{l}\text { - providing } \\
\text { framework } \\
\text { conditions }\end{array}$ & $\begin{array}{l}\text { - invest \& exert pressures } \\
\text { - receive services \& } \\
\text { benefits }\end{array}$ \\
\hline $\begin{array}{c}\text { interests \& } \\
\text { preference } \\
\text { structures }\end{array}$ & $\begin{array}{l}\text { - generate knowledge } \\
\text { - make a professional }\end{array}$ & - specific policy goals & $\begin{array}{l}\text { - good balance of costs \& } \\
\text { benefits }\end{array}$ \\
\hline $\begin{array}{c}\text { resources \& } \\
\text { competencies }\end{array}$ & $\begin{array}{l}\text { - expert knowledge } \\
\text { - communication }\end{array}$ & $\begin{array}{l}\text { - legal \& financial } \\
\text { - resources } \\
\text { - communication }\end{array}$ & $\begin{array}{l}\text { - control (property, } \\
\text { entitlement, licence,...) } \\
\text { - communication }\end{array}$ \\
\hline $\begin{array}{c}\text { major } \\
\text { categories }\end{array}$ & - onsite | offsite & $\begin{array}{l}\text { - onsite | offsite } \\
\text { - government | NGO } \\
\text { - scale level }\end{array}$ & $\begin{array}{l}\text { - onsite | offsite } \\
\text { - productive | consumptive } \\
\text { - economic sectors }\end{array}$ \\
\hline
\end{tabular}


- The sustainability of a BR depends not only on sustainable interactions between the social and the natural systems (,,internal sustainability"),

- but also on the sustained support from all important stakeholders (,external sustainability").

- Therefore, stakeholder involvement has to be continuously observed and strenghtened. 


\section{stakeholders and users of BRs}

\begin{tabular}{c|l|l|l}
\hline \multicolumn{1}{|c|}{ scientists } & decision makers & \multicolumn{1}{c}{ users } \\
\hline $\begin{array}{c}\text { Interactions } \\
\text { with BR } \\
\text { ecosystem }\end{array}$ & $\begin{array}{l}\text { - measuring, monitoring, } \\
\text { assessments }\end{array}$ & $\begin{array}{l}\text { - providing } \\
\text { framework } \\
\text { conditions }\end{array}$ & $\begin{array}{l}\text { - invest \& exert pressures } \\
\text { - receive services \& } \\
\text { benefits }\end{array}$ \\
\hline $\begin{array}{c}\text { interests \& } \\
\text { preference } \\
\text { structures }\end{array}$ & $\begin{array}{l}\text { - generate knowledge } \\
\text { - make a professional }\end{array}$ & - specific policy goals & $\begin{array}{l}\text { - good balance of costs \& } \\
\text { benefits }\end{array}$ \\
\hline $\begin{array}{c}\text { resources \& } \\
\text { competencies }\end{array}$ & $\begin{array}{l}\text { - expert knowledge } \\
\text { - communication }\end{array}$ & $\begin{array}{l}\text { - legal \& financial } \\
\text { - resources } \\
\text { - communication }\end{array}$ & $\begin{array}{l}\text { - control (property, } \\
\text { entitlement, licence,...) } \\
\text { - communication }\end{array}$ \\
\hline $\begin{array}{c}\text { major } \\
\text { categories }\end{array}$ & - onsite | offsite & $\begin{array}{l}\text { - onsite | offsite } \\
\text { - government | NGO } \\
\text { - scale level }\end{array}$ & $\begin{array}{l}\text { - onsite | offsite } \\
\text { - productive | consumptive } \\
\text { - economic sectors }\end{array}$ \\
\hline
\end{tabular}




\section{Integrated monitoring - sustainability assessment \& management (fig $1^{\star}$ )}

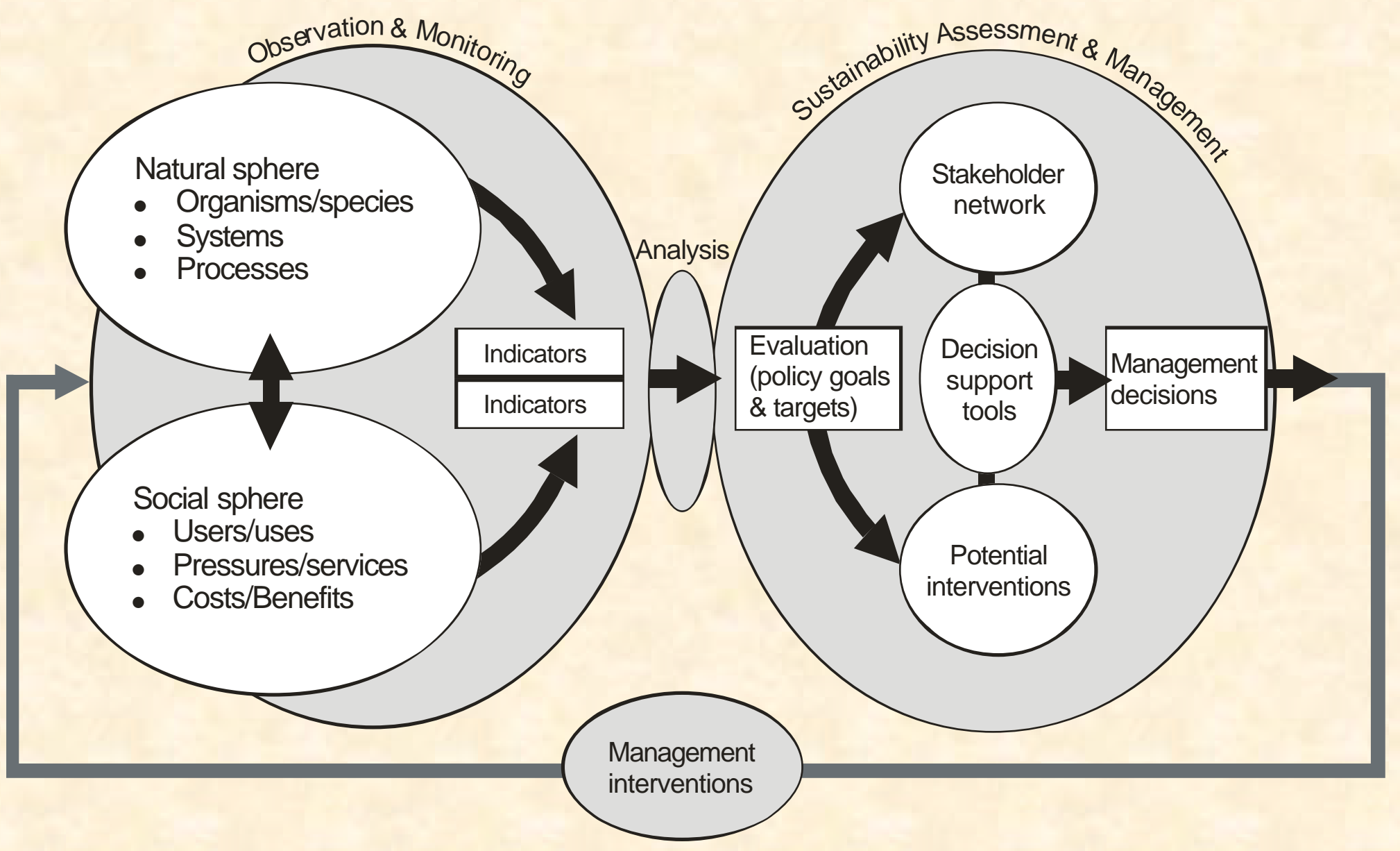




\section{of a social monitoring programme}

1. Conceptual model of the system

2. Set of indicators

3. Methodology for data collection \& storage

4. Methodology for calculating indicators

5. Process for synthesis

6. Methodology for reporting

7. Effective communication

8. Broad participation

9. Institutional capacity

10. Guiding vision and goals 